\title{
An Exploratory Study of Performance-Based Budgeting Practices in Indonesian Private School
}

\author{
Agus Wahyudin, Agung Yulianto, Badingatus Solikhah \\ Accounting Department \\ Universitas Negeri Semarang \\ Semarang, Indonesia \\ aguswahyudin@mail.unnes.ac.id, agungfe@mail.unnes.ac.id, badingatusbety@mail.unnes.ac.id
}

\begin{abstract}
The demands of bureaucratic reform are challenges and prospects for educational institutions. In Indonesia, private school management has a very different character from public schools because it has a high financial dependence on foundations. Sources of funding at private schools come from parents, foundations, governments, donations/grants. Prior research provided empirical evidence that the implementation of planning and budgeting in schools has not been well managed and it has many obstacles. The purpose of this paper was to explore the budgeting process, stakeholder participation level, the constraints in the budgeting process, and the implementation of performance-based budgets in vocational high schools. The research was conducted in three private schools around Semarang City Indonesia. Respondents in this research were principals, treasurers, foundation boards, committees, teachers, students, staff, and parents. The results showed that the budget in private schools has not been based on vision, mission and school goals. The funds mostly used to finance the daily activities in teaching and learning. The most dominant role in determining the budget post was the treasurer and the board of the foundation, it because of the lack of human resources. The school budget in the autonomy era is expected to be formulated with a performance approach that prioritizes the achievement of goals.
\end{abstract} budget

Keywords-budgeting; performance based budgeting; school

\section{INTRODUCTION}

The demands of good corporate governance in both public and private sector increase, the management must be professional, transparent and accountable [1]. The school budget in the autonomy era is expected to be prepared with a performance approach that prioritizes on achieving goals. Budget is an important element in management that serves as a planning tool for managers to manage the organization well [2]. The first budget function is as a planning tool in a broader sense including activities to predict economic resources and allocate them to operationalize work programs to achieve organizational goals effectively and efficiently [3], [4].

Performance-based budgeting is a budget in which organizational attention leads to goal attainment. Therefore, the organization must be able to link explicitly allocation of resources or expenditure toward the organization goals to be achieved. The critical issues facing the institution is how to allocate the resource based on activities for achieving measurable outcomes specifically, through a strategic planning process taking into account, agency capabilities, and stakeholder input [5].

In Indonesia and most countries in the world, financial management in private schools and government schools is of course different. In public school schools, budget planning always involves parents of students, school assemblies and compliance with education finance budgeting procedures in accordance with regulations issued by the government but not fully optimal. While the private school schools have very different implications depending on the foundation that shelter it and the parents environment of the students/community as stakeholders.

The empirical phenomenon shows that the implementation of planning and budgeting on school management is still not optimal and faces some difficulties [6]. Many educational institutions, especially private schools that are closed and unable to survive due to financial management. Research Hermawan also produced the same report that financial reporting of Muhammadiyah University in Sidoarjo still use traditional budget report model [7].

Other issues related to budgeting such as participation rates, budget gaps, and performance indicators have been the focus of many researchers. These studies are, among others, carried out by [8], [9], [10], [11]. Other researchers have studied the budget by adopting contingent approaches, among others, by [12], [13]. Therefore, budgeting that serves as a school management planning tool is very strategic and important to the situation and conditions of decentralization education policy in which educational institutions are required to improve accountability, and their financial performance, the efficiency of organizational resource management in order to produce productive outcomes to the entire stakeholders.

\section{LITERATURE REVIEW}

\section{A. Contingency Theory}

Grand theory used as a foundation for this research is Contingency Theory. Contingency theory is based on the premise that no financial management system (including budgeting) is universally always appropriate to apply to the entire organization since the success of management depends on situational factors that exist outside or within the 
organization. Contingency theory can be used to analyze the design and management accounting system to provide information that companies can use for various purposes [14].

\section{B. Overview of Budget}

The budget as one of the management tools plays an important role in management because it serves to plan, organize and evaluate the program and activity of an organization. Factors to consider in the preparation of the budget are as follows:

- Knowledge of corporate organization goals and policies.

- Time series data in the past.

- Possible development of the condition of society.

- Knowledge of techniques, competitors 'strategies and competitors' movements.

- Possible changes to government policy.

- Research for the development of corporate organization.

\section{Performance-Based Budget}

The performance-based budget is: "The budget system is more emphasis on the utilization of available funds to achieve optimal results [15]. Budgeting undertook with due consideration of the interrelationship between outputs and expected outcomes of activities and programs including efficiency in achieving outputs from those outcomes [16].

\section{Characteristics of Performance-Based Budgets}

Characteristics of performance-based budgets from various sources [17], [11], [18] are as follows:

- Classify accounts in budgets by function and activity and also by organizational unit and shopping details.

- Investigate and engage in activities to achieve maximum efficiency and to obtain cost standards.

- Basing the budget for the period to come at standard cost each unit times multiplied by the number of units of activity expected to be done at a certain period.

In the framework of the implementation of performancebased budget there are the main elements that must be determined first, namely: vission, mission, goal, target, program, and activity [19].

\section{METHOD}

This paper used a qualitative research design to answer research questions. This research was conducted at Private Vocational High School in Semarang City, Indonesia. The data and information that have been collected are from 3 schools namely: Vocational High School "Perintis 29-01", Vocational High School "Palebon" and Vocational High School "Muhamadiyah". Respondents in this research were principals, treasurers, foundation boards, committees, teachers, students, staff, and parents. Respondents interviewed for each school were 8 persons per school. Data collection methods used in this research are (1) questionnaire; (2) interviews; and (3) documentation. Furthermore, the data were analysed and explored by qualitative study to answer the research question: budgeting process; stakeholder participation level; constraints emerging in the budgeting process; and implementation of performance-based budgets in vocational high schools.

\section{RESULT AND DISCUSSION}

\section{A. Budgeting Process of Private Vocational Schools in Semarang City}

In general, the process of preparing the budget at private schools in Semarang City through the following stages:

\section{1) Evaluate the current state of the school}

a) Evaluate school performance in the previous year

b) Compare the performance evaluation results with the school standard reference

2) Establish expected school conditions for the foreseeable future

a) Formulate goals and performance indicators

b) Formulating future school (priority) challenges

3) Develop work programs

a) Formulate programs and assign program responsibilities schedules

b) Formulate activities, activity indicators, and activity

4) Formulate a school budget plan: In schools that have several programs / majors, the preparation of the budget to finance the learning process is done by each program. Furthermore, the budget proposals from each unit will be consolidated with budgets from other units and discussed by the headmaster and principal.

\section{B. The Party Involved in the Budgetsing}

School Budget Income and Expenditure Plan should be able to accommodate the interests of all school stakeholders so that participative budgeting is a strategy to achieve an accommodative and efficient budget. Budgeting should involve all school stakeholders consisting of principals, foundation managers, treasurers, school committees, teachers, staff representatives, and student representatives. But the fact that the budget is only made up by a small number of people who usually consists of the board of foundations, principals and treasurers. As a result, due to the limited number of funds, sometimes the determination of the budget priority scale is not appropriate

\section{Source of Fund in School Budget}

In general, the source of funds for private vocational schools is derived from the following 3 sources:

- Funds from the public: these funds can be either Operational Contributions or donations for infrastructure development paid once by parents, in 
addition, funds from the community from school payments paid each month. This fund occupies the largest proportion that is in the range of $60 \%-90 \%$ of all funds received by the school.

- Funds from the government: government funds are of various kinds, including assistance to poor students called school operational assistance (BOS), funds from local government allocated from government education budgets, as well as scholarships granted from the government. These funds, although they come from the government but the proportion is not too large from the total school funds. Likewise, for the use of these funds is set and limited allocation of spending.

- Funds come from outsiders: this funding from outsiders means that funds are provided outside the parents and the government. For example, from industry that cooperate with school, gain from business / school entrepreneur, and grant fund from outside party.

\section{Budget Allocation}

The greatest fund of school budget is usually used for school operational activities such as paying the salaries of staff (teachers and staff), student activities, curriculum development and learning activities, purchasing office supplies, laboratory materials and equipment, meeting activities, transportation and travel, and power and service costs. The funds also use to improve the competence of teachers and education personnel, but the allocation of funds for this component is not large. A small amount of budget is also used for school equipment investment such as procurement of learning facilities and infrastructure.

\section{E. Constraints in Budgeting}

The following outlines some of the issues that often arise in the school budgeting process by using a systematic approach in the context of decentralized education.

- The proposed budget is based on available money and is not supported by adequate staff knowledge, so the forcasting are often mistaken.

- Staff do not understand the importance of the budget, so the budget is usually made with reference to the previous year's budget.

- There is a decrease in the amount of education budget received from the government so that the school development becomes obstructed

- Lack of ability to evaluate budget proposals

- There is a threat of budget centralization (top down budgeting) from the foundation

- Lack of coaching, communication and consultation with related parties

- Limited budgeting time

\section{F. Discussion}

Budget is an element of the management process that serves as a planning tool so that managers can carry out organizational activities effectively and efficiently. The budget process at the school that is the object of observation in this paper still uses the traditional method. Empirical facts based on previous research [20], [21] show that the process of budgeting in educational institutions with conventional approaches contains many weaknesses. Therefore, Vocational High School "Pioneer 29-01", Vocational High School "Palebon" and Vocational High School "Muhamadiyah" should implement a performance-based budget. Performance-based budgeting is a program planning system that will be done by an organization by setting performance benchmarks as a benchmark in achieving goals. Performance-based budgets are structured to address the various weaknesses of the traditional budget system, especially the disadvantages caused by the absence of benchmarks that can be used to measure performance in achieving goals and objectives.

\section{CONCLUSION}

In general, the process of preparation and execution of the budget in private vocational schools in the city of Semarang intended to finance the routine activities of learning. The proportion for investment in human resource development is still small. The budgeting process has not fully led to the achievement of school vision and goals. School Revenue and Expenditure Budget Plan (RAPBS) should be prepared based on the school development plan in order to achieve the school's vision and objectives in the long term. School budget at least to finance teaching activities, class materials, human resources development, renovation of school buildings, maintenance of infrastructure, book purchases, and procurement of school infrastructure. Budgeting should involve all school stakeholders consisting of principals, treasurers, school committees, foundation managers, teachers, staff representatives, and student representatives. Budgeting at private vocational schools in Semarang City has not been fully based on achieving the vision, mission or school goals, but more for the financing of routine activities that are relatively the same from the previous year.

Further research may expand the object of research on other types of schools, such as non-vocational schools to obtain a more comprehensive conclusion. Vocational education requires greater operational costs than other types of schools, hence school leaders and foundations must be able to efficiently manage budgets based on achieving school vision and goals.

\section{REFERENCES}

[1] Gonzales, T. Racho, A. Martinez, and Bordon, Transparancy Community and Accountability In The Education System "Mexico's Right to Know Reforms Civil Society Perspectives, Section V - Social Policy, 2007.

[2] P. Chalos, "An Examination of Budgetary Inefficiency in Education Using Data Envelopment Analysis," Financial Accountability and Management, vol. 13, pp. 289-304, 1997. 
[3] E.A. Hanushek, "Expenditures Efficiency And Equite Education The Federal Government Rule," The American Economic Review, vol 79, No. 2, pp. 46 - 51, 1989.

[4] Munandar, Budgeting: Planning, Coordinating and Monitoring Work, 1st ed, Yogyakarta: BPFE Press, 2000.

[5] H. Singh, and P. Mahajan, "Relationship between budget allocation and growth of resources at the university libraries of Northern India a study," Collection Building, vol. 36, No. 3, pp.127-134, 2017.

[6] Yahya, Educational Financing Management System A Study on Funding for Primary School Education in West Sumatra Province, (Thesis, Bandung, Universitas Pendidikan Indonesia), 2003.

[7] S. Hermawan, "Application of Balance Scorecard as a Strategy Implementation Tool to Improve the Performance of Muhammadiyah University of Sidoarjo," Jurnal Ekonomi Bisnis dan Akuntansi VENTURA, vol. 11, No. 2, pp 1-18, 2008.

[8] I. Kenis, "Effects of Budgetary Goals Characteristics on Managerial Attitudes and Performance," The Accounting Review, vol. 54, No. 4, pp. 707-721, 1979.

[9] V. Frucot, and W. Shearon, "Budgettary Partisipation Locus Of Control and Mexican Manajerial Performance and Satisfaction," The Economic Review, pp. 8 - 19, January 1991.

[10] N. Indriantoro, The Effec Partisipation Budgetting on Job Performance and Job Satisfaction With Locus Of Control and Cultural Dimension as Moderating Variables, University Of Kentucky Desertation, 1993.

[11] S.A. Kenno, and B. Sainty, "Revising the budgeting model: challenges of implementation at a university, Journal of Applied Accounting Research, vol. 18, No. 4, pp.496-510, 2017.
[12] V.K. Chong, and K.M. Chong, "Budget Goal Commitment and Informational Effects of Budget Participation on Performance: A Structural Equation Modeling Approach," Behavioral Research in Accounting, vol. 14, pp. 65-86, 2002.

[13] R. Venkatesh, and J. Blaskovich, The Mediating Effect of Psychological Capital on the Budget Participation-Job Performance Relationship, Journal of Management Accounting Research, vol. 24, No.1, pp.159-175, 2012

[14] D.T. Otley, "The contingency theory of management accounting: Achievement and prognosis, Accounting, Organizations and Society,' Elsevier, vol. 5, No. 4, pp. 413-428, 1980.

[15] S. Yuwono, A. Indrajaya, and Hariyandi, Public Sector Budgeting, 1st ed, Jawa Timur : Bayumedia, 2005.

[16] N. Darise, Accounting for Government Finance (Public Sector Accounting), Jakarta : PT Indeks Press, 2008.

[17] W. O'Grady, C. Akroyd, and I. Scott, Beyond Budgeting: Distinguishing Modes of Adaptive Performance Management, in Mary A. Malina (ed.) Advances in Management Accounting Advances in Management Accounting, vol 29, 2017, pp.33 - 53.

[18] Z. Alach, "The use of performance measurement in universities. International Journal of Public Sector Management," vol. 30, No. 2, pp.102-117, 2017.

[19] Mardiasmo, Autonomy and Financial Management of Government, Yogyakarta : Penerbit Andi, 2002

[20] Firdaus, Management of Education Financing and Its Impact on School Productivity : Study at State Madrasah Tsanawiyah in Kabupaten Cianjur, (Thesis, Cianjur), 2005.

[21] D. Supriadi, Unit Cost of Primary and Secondary Education. Bandung : Rusdi Karya Press, 2006. 